\title{
OPEN GOVERNMENT DATA QUALITY ASSESSMENT IN WESTERN BALKAN COUNTRIES
}

\author{
Vigan Raça ${ }^{1}$, Natasa Veljkovic ${ }^{2}$ and Goran Velinov ${ }^{1}$ \\ ${ }^{I}$ Ss. Cyril and Methodius University in Skopje, North Macedonia \\ ${ }^{2}$ University of Nis, Serbia
}

\begin{abstract}
In recent years, open government data has gained attention among academics, practitioners, and policy analysts. One of the fundamental dimensions of open government data is its quality. Qualitative data are data that can be effectively used and reused for various purposes ranging from evidenced-based decision-making to the fight against corruption. Open government data initiatives are present in the Western Balkans, as well. The aim of this paper is to identify and assess the quality dimension of all open government data in Balkan countries. To reach the set goal, this paper employs the " 5 star" methodology of Berners-Lee. First, the paper identifies all datasets available in open government portals in all six Balkan countries. Second, it analyses and classifies them employing the " 5 Star" methodology. Third, it aims to find out the relation between the date the countries become members of open government partnership and their implementation scale. The results show that Balkan countries have 76-305 government datasets available online as part of the open government data framework. The assessment depicts that these data suffer from poor quality. This research does not observe any correlation between the year the country joined the OGP, the number of datasets available, and the quality of data. Overall, in practice, Balkan countries have still a long way to go to fully embrace the concept of open government data.
\end{abstract}

\section{KEYWORDS}

Open Government Data, Data Quality, Public Sector, Western Balkans

\section{INTRODUCTION}

The common understanding of the open data notion is simple-freely used, re-used and redistributed data by anyone without restrictions from copyright, patents or other mechanisms of control (Berners-Lee et al, 2006). Open data refers to all data including those of governments, non-government stakeholders like businesses, educational institutions, NGOs and similar. One crucial aspect of open data is the Open Government Data (hereinafter OGD). The OGD is a narrower concept compared to open data. According to (Rosnay et al, 2014), the term of OGD is related to machine-readable data that is available from governments or by government agencies under open license conditions that permit further commercial or non-commercial use of data. The birth of OGD originated in the Memorandum of Transparency and Open Government, signed by Obama, in 2009 (Obama Whitehouse, 2009).

The aim of the memorandum was to establish an open system of transparency and openness in the administration. On the basis of the OGD, in 2011 the Open Government Partnership (hereinafter the OGP) was established (Open Government Partnership, 2011). The OGP has seventy-eight countries and twenty local members representing about two billion people. All Western Balkan countries excluding Kosovo, are formal members of the OGP. OGP members have to sign an open government declaration and commit to implementing it by establishing action plans in cooperation with other stakeholders. The benefits of OGD range from more effective fight against corruption, higher transparency and accountability to more evidence based decision-making (Schrier Bill, 2014).

Moreover, production of such data through e-government is also considered recognition of the potential economic value (Janssen et al. 2012) he European Commission Vice-President, Neelie Kroes, highlighted that economic potential of OGD is high, estimated value was placed at 40 billion euros each year, he also urged EU governments to release more information on the public information sector, saying "Your data is worth more if 
you give it" (Neelie, 2011). While, according to Tinholt "The aggregate economic impact from applications based on Open Data across the EU27 economy is estimated to be $€ 140$ billion annually" (Tinholt, 2013).

Apart from various benefits of implementing OGD, the countries are also faced with a number of challenges related to implementation. (Ubaldi, 2013). The challenges encountered can include the lack of any standard process for publication of OGD, unclear and missing values, erroneous data, lack of systematic measurements of data quality (Zuiderwijk et al., 2014), this research focuses only in open government data quality and the potential for reusing this data.

The paper is structured as follows: section II discusses the methodology; section III provides an analysis on the current situation of OGD in WB Countries; section IV discusses the results and provides a conclusion.

\section{METHODOLOGY}

With the purpose of analyzing the quality of open data by governments we employ the methodology of Berners-Lee, also known as the 5-star classification methodology.

Table 1. Star Plan Model (http://5stardata.info/en)

\begin{tabular}{|c|c|}
\hline Rating & Description \\
\hline$\star$ & available on the web (whatever format) but with an open \\
\hline$\star \star$ & $\begin{array}{c}\text { available as machine-readable structured data (e.g. excel instead of } \\
\text { image scan of a table) }\end{array}$ \\
\hline$\star \star \star$ & as (2) plus non-proprietary format (e.g. csv instead of excel) \\
\hline$\star \star \star \star$ & $\begin{array}{l}\text { all the above plus, use open standards from w3c (rdf and sparql) to } \\
\text { identify things, so that people can point at your stuff }\end{array}$ \\
\hline 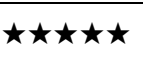 & $\begin{array}{c}\text { all the above, plus: link your data to other people's data to provide } \\
\text { context }\end{array}$ \\
\hline
\end{tabular}

This research identifies all ODG portals in Balkans and assesses all of them according to the 5 star methodology. As shown in table 1, once a dataset is published in whatever format, yet it is open to the public, it is rated with one star presenting the poorest condition of open data. On the other hand, once a dataset is published online, easily downloaded and reused, and possible to be linked to other datasets, amongst other features, it is rated with a five star presenting high quality data. This methodology also offers us a basis for comparison across Western Balkans as all countries are assessed with the same method. In addition, research also aims to find out if there is any relation between the date the countries signed the OGP, the number of datasets available online and their state of play in OGD quality.

\section{ANALYSIS OF OPEN GOVERNMENT DATA IN WESTERN BALKAN COUNTRIES}

All Western Balkan countries have signed the OGP declaration and are members of the OGP, but Kosovo. As shown in the below table, each country has a national OGP portal with a different number of available datasets ranging from 76 (Montenegro) to $305(\mathrm{BiH})$. 
Table 2. OGD Portals in Western Balkan Countries

\begin{tabular}{|l|l|l|}
\hline Country & OGD Portal & $\begin{array}{l}\text { Dataset } \\
\text { s }\end{array}$ \\
\hline Albania & http://open.data.al/ & 145 \\
\hline Bosna \& Herzegovina & https://opendata.ba/ & 305 \\
\hline Kosovo & https://opendata.rks-gov.net/ & 195 \\
\hline North Macedonia & $\begin{array}{l}\text { http://www.otvorenipodatoci.gov.mk } \\
/\end{array}$ & 215 \\
\hline Montenegro & https://data.gov.me/ & 76 \\
\hline Serbia & https://data.gov.rs/sr/ & 265 \\
\hline
\end{tabular}

In the below sections this research analyses each country individually.

$\underline{\text { Albania }}$

Albania is a member of OGP since 2011, and the key institution in charge of OGP is the Ministry of State for Innovation and Public Administration. On 10th January, 2019 Albania adopted its $4^{\text {th }}$ action plan (2018-2020) which is still being implemented. This action plan includes 4 commitments related to fiscal transparency, public services, access to information, public administration, and anti-corruption (Open Government Partnership, 2019).

In Albania, the OGD national portal is recently redesigned and has a higher number of datasets, and organizations that joined the initiative, totaling to 15 institutions. In the following table we present an overview of the current situation referring to the main attributes of OGD including datasets and organizations. According to the data presented in the above table, the highest number of datasets published are rated with one and with four stars. The total number of datasets available is 145, 69 of which are assessed with one star, 66 with four star, and 10 with two star. It is important to note that none of the organizations have published in CSV or LINKED format (Opendata.gov.al, 2019).

Table 3. Information related to OGD in Albania

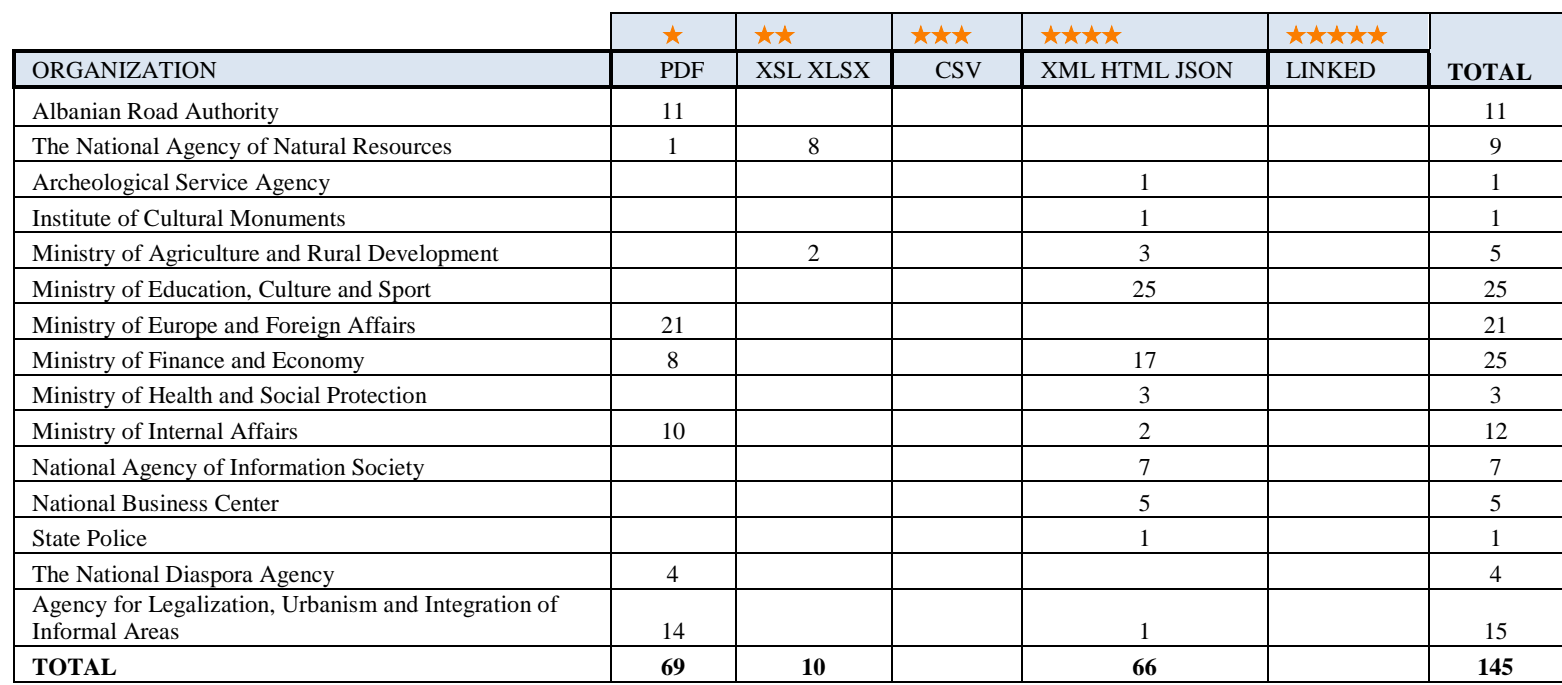

North Macedonia

The Republic of North Macedonia joined the OGP in 2011. Since then the Government of North Macedonia has adopted three Action Plans in 2012, 2014 and 2016. Recently the Government of North Macedonia on $12^{\text {th }}$ September 2018 adopted its 4th OGP National Action Plan (2018-2020) that has 23 commitments for active work on the priorities related to access to information, fiscal transparency, integrity and good governance, open data and transparency at local level (Open Government Partnership, 2019). 
In North Macedonia, the number of organizations that have joined the initiative is 21 . The number of published datasets is also higher totaling to 206. The table below shows the current number of organizations, and datasets published in various formats. The highest number of datasets are assessed with a two star, while no dataset is assed as five star. 153 out of 206 are published in XLS and XLSX star, 48 in CVS format, 4 in PDF, 1 in XML HTML JSON, and none in LINKED format (Otvorenipodatoci.gov.mk, 2019).

Table 4. Information related to OGD in North Macedonia

\begin{tabular}{|c|c|c|c|c|c|c|}
\hline & $\star$ & $\star \star \star ⿰ 丿 ⿱ 丄 𠃍$ & 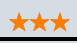 & 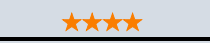 & 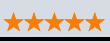 & \\
\hline ORGANIZATION & PDF & XSL XLSX & CSV & XML HTML JSON & LINKED & TOTAL \\
\hline Ministry of Labor and Social Policy & & 1 & 22 & & & 23 \\
\hline Ministry of Finance & 1 & 21 & & & & 22 \\
\hline Ministry of Interior & & 20 & & & & 20 \\
\hline Agency of Administration & & 18 & & & & 18 \\
\hline Employment Service Agency & & 10 & & & & 10 \\
\hline State Inspectorate for Urban Planning & 3 & 6 & & & & 9 \\
\hline Hydro system Zletovica & & 9 & & & & 9 \\
\hline State Inspectorate for Agriculture & & 8 & & & & 8 \\
\hline Ministry of Economy & & 8 & & & & 8 \\
\hline Ministry of information Society and Administration & & 3 & 7 & & & 10 \\
\hline Water Supply Studentica & & 5 & & & & 5 \\
\hline Ministry of Environment and Physical Planning & & 6 & & & & 6 \\
\hline Inspection Council & & 13 & 4 & & & 17 \\
\hline Agency of Electronic Communication & & 3 & & & & 3 \\
\hline State Administration Inspectorate & & 4 & & & & 4 \\
\hline National Extension Agency & & 3 & & & & 3 \\
\hline Ministry of Justice & & 3 & 15 & & & 18 \\
\hline Agency of Medicines and Medical Equipment & & 3 & & & & 3 \\
\hline Directory for Radioactive Safety & & 6 & & & & 6 \\
\hline Public Enterprise Strasevo Bitola & & 1 & & 1 & & 2 \\
\hline Public Enterprise Agro-Berza & & 2 & & & & 2 \\
\hline TOTAL & 4 & 153 & 48 & 1 & & 206 \\
\hline
\end{tabular}

$\underline{\text { Montenegro }}$

Montenegro joined the OGP on $13^{\text {th }}$ February 2012. Currently, it is completing its $2^{\text {nd }}$ action plan, adopted on $21^{\text {st }}$ of November 2018. This action-plan features commitments related to access to information, citizen participation, public services and anti-corruption (Open Government Partnership, 2019).

Montenegro has the lowest number of datasets available compared to all Western Balkans countries, totaling to 76, and it has 16 organizations that have joined the initiative. As shown in the below table, all datasets are assessed with a four star, meaning that they are available in one of the three formats (XML, HTML, JSON). Though the country has the lowest number of datasets available, none of datasets is assessed with one star, two star, three star, or five star (Opendata.me, 2019). 
Table 5. Information related to OGD in Montenegro

\begin{tabular}{|c|c|c|c|c|c|c|}
\hline & $\star$ & $\star \star \star$ & $\star \star \star \star$ & 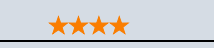 & 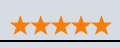 & \\
\hline ORGANIZATION & PDF & XSL XLSX & CSV & XML HTML JSON & LINKED & TOTAL \\
\hline Ministry of Labor and Social Welfare & & & & 5 & & 5 \\
\hline Ministry of Human and Minority Rights & & & & 1 & & 1 \\
\hline Ministry of Education & & & & 9 & & 9 \\
\hline Agency for Peaceful Settlement of Labor Disputes & & & & 1 & & 1 \\
\hline Ministry of Finance & & & & 1 & & 1 \\
\hline Agency for Medicine and Medical Devices & & & & 2 & & 2 \\
\hline Institute of Metrology & & & & 2 & & 2 \\
\hline Ministry of Rural and Agriculture Development & & & & 3 & & 3 \\
\hline Ministry of Economy & & & & 1 & & 1 \\
\hline Ministry of Transport and Marine & & & & 5 & & 5 \\
\hline Institute for Social and Childs Welfare & & & & 7 & & 7 \\
\hline Ministry of Truism and Sustainable Development & & & & 7 & & 7 \\
\hline Ministry of Justice & & & & 7 & & 3 \\
\hline Ministry of Science & & & & 3 & & 3 \\
\hline Ministry of Public Administration & & & & 6 & & 6 \\
\hline Labor Found & & & & 16 & & 16 \\
\hline TOTAL & & & & 76 & & 76 \\
\hline
\end{tabular}

Bosnia and Herzegovina

Bosna and Herzegovina (hereinafter $\mathrm{BiH}$ ) joined the OGP on September 2014. After joining the OGP, the $\mathrm{BiH}$ Council of Ministers issued a special request to all ministries, public institutions and agencies to start planning the adoption of open government policies in order to increase transparency and accountability of public services. They were also instructed to adopt the decision on the establishment of the Advisory Committee of the OGP responsible for monitoring $\mathrm{BiH}$ authorities in terms of OGD. However, in practice, the Committee is not working completely due to the permanent political problems with the other part of $\mathrm{BiH}$ (Republika Srpska), which is functioning as an independent body of $\mathrm{BiH}$. Currently, $\mathrm{BiH}$ is implementing the $1^{\text {st }}$ Action Plan (2019-2021) including 7 commitments related to open data, public procurement, anti-corruption, integrity, proactive disclosure of public data, budget for citizens, and improving public consultations (Open Government Partnership, 2019).

$\mathrm{BiH}$ has the highest number of datasets available in the region and the lowest number of organizations, 316 and 9, respectively. No datasets are available in XML, HTML, JSON or LINKED format. One is assessed with one star, while the others are assessed with one (148 out of 316) and with three starts (167 out 316) (Opendata.ba, 2019).

Table 6. Information related to OGD in Bosna \& Herzegovina

\begin{tabular}{|l|c|c|c|c|c|c|}
\cline { 2 - 6 } \multicolumn{1}{c|}{} & $\star$ & $\star \star$ & $\star \star \star$ & $\star \star \star \star \star$ & $\star \star \star \star \star$ & \multirow{2}{*}{ TOTAL } \\
\hline ORGANIZATION & PDF & XSL XLSX & CSV & XML HTML JSON & LINKED & \\
\hline Law Institutions of BiH and Federation & 102 & & & & & 70 \\
\hline Public Finances - Budged & & & 157 & & & 22 \\
\hline Agency for Statistics of BiH & 20 & & 2 & & & 13 \\
\hline Federal Bureau of Statistics & 13 & & & & & 6 \\
\hline Center for Social Research Analytics & 6 & & & & & 3 \\
\hline Institute for Public Health of BiH Federation & 3 & & & & & 2 \\
\hline State Regulation & 2 & & & & & 1 \\
\hline BiH Parliament & 1 & & & & & 10 \\
\hline Institute of Statistics of Republika Srpska & 1 & 1 & 8 & & & $\mathbf{3 1 6}$ \\
\hline TOTAL & $\mathbf{1 4 8}$ & $\mathbf{1}$ & $\mathbf{1 6 7}$ & & & \\
\hline
\end{tabular}


$\underline{\text { Serbia }}$

Serbia joined the OGP in 2012, while in 2014 the Government of Serbia adopted its $1^{\text {st }}$ action plan including public integrity, information access, further development of public services on the central and local administration, e-government portal, multi-channel approach service, civil society, fight against corruption and efficient management of public resources. Currently Serbia is implementing $3^{\text {rd }}$ Action Plan (2018-2020) adopted on January 2019 that includes 14 commitments related to open data, fiscal transparency, access to information, public services and transparency of the Parliament (opengovpartnership.org). The institution in charge of developing and implementing policies that derived from signing the OGP declaration is the Ministry of Public Administration and Local Self-Government in Serbia (Open Government Partnership, 2019).

In Serbia, 23 organizations have joined the initiative and they have published 265 datasets. As for other country case studies we have analyzed each organization; however, for Serbia we had to go further due to the fact that some of the data exported was in unusual formats (ZIP), thus it was necessary to check compressed files in order to find out the data format. There were some other formats, which are not included in 5 Star Schema but we have used equivalence for these formats. For example GPX format is equivalent with XML, so we've classified it as XML in order to meet the "5 Star" model assessment. As shown in the below table, the highest number of datasets, 110 out of 265 are assessed with two star and none is assessed with five star (Data.gov.rs, 2019).

Table 7. Information related to OGD in Serbia

\begin{tabular}{|c|c|c|c|c|c|c|}
\hline & $\star$ & 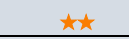 & 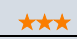 & 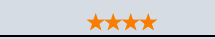 & $\star x t \pi x t$ & \\
\hline Agency for Environmental Protection & & & 17 & 3 & & 20 \\
\hline Ministry of Internal Affairs & & 1 & & 1 & & 2 \\
\hline Agency for Health and Welfare Protection & & & 19 & 3 & & 24 \\
\hline Commissioner for Information of Public Importance & & 16 & & & & 16 \\
\hline Ministry of Minerals and Energy & & & 1 & 8 & & 9 \\
\hline The Office for IT and e-Government & & & 3 & & & 3 \\
\hline Statistical Office of Serbia & & & & 27 & & 27 \\
\hline Republic Geodetic Authority & & & & 3 & & 3 \\
\hline Ministry of Culture and Information & & & 3 & 11 & & 14 \\
\hline Social Innovation observatory & & 1 & & & & 1 \\
\hline Institute of Public Health of Serbia & & & 3 & & & 3 \\
\hline Directorate for Agrarian Payments & & 3 & & & & 3 \\
\hline GIS Association of Serbia & & & & 1 & & 1 \\
\hline Agency for Traffic Safety & & & & 3 & & 3 \\
\hline Office for Civil Society Cooperation of Serbia & & 1 & & 1 & & 2 \\
\hline Ministry of Construction, Transport and Infrastructure & & 1 & & & & 1 \\
\hline National Library of Serbia & 1 & & & 2 & & 2 \\
\hline TOTAL & 2 & 110 & 65 & 87 & & 265 \\
\hline
\end{tabular}

\section{$\underline{\text { Kosovo }}$}

Kosovo is not yet an official member of the OGP against many unsuccessful efforts complied toward joining the OGP. It has applied in 2014, but its application has been rejected due to the political position of Kosovo and some technical criteria that have not been completed, according to them. No matter its status in the OGP, the country has assigned the Ministry of Public Administration, respectively the Agency of Information Society to lead the implementation, supervision monitoring of their OGD portal and its further development. Recently, Kosovo has re-designed open government data portal by implementing a new technology for dataset collection and has integrated a rule which regulates publishing of data. 
Kosovo has 13 organizations that have published 195 datasets. As shown in the below table, almost all of its datasets, 189 out of 195 are published in CVS format -rated with 3 star, while only six are published in XLS or XLSX format (Opendata.rks-gov.net, 2019).

Table 8. Information related to OGD in Kosovo

\begin{tabular}{|c|c|c|c|c|c|c|}
\hline & $\star$ & $\star \star \star$ & 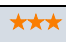 & 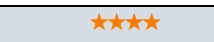 & 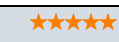 & \\
\hline ORGANIZATION & PDF & XLS, XLSX & CSV & XML HTML, JSON & LINKED & TOTAL \\
\hline Kosovo Statistical Agency & & & 3 & & & 3 \\
\hline Agency Anti-Corruption & & & 6 & & & 6 \\
\hline Independent Oversight Board Civil Service & & & 4 & & & 4 \\
\hline Public Procurement Regulatory Commission & & 6 & & & & 6 \\
\hline Ministry of Economic Development & & & 8 & & & 8 \\
\hline Ministry of Environment and Spatial Planning & & & 7 & & & 7 \\
\hline Agency for Environment Protection & & & 5 & & & 5 \\
\hline Kosovo Customs & & & 6 & & & 6 \\
\hline Ministry of Health & & & 91 & & & 91 \\
\hline Ministry of Labor and Social Welfare & & & 22 & & & 22 \\
\hline Ministry of Public Administration & & & 18 & & & 18 \\
\hline Kosovo Institute for Public Administration & & & 17 & & & 17 \\
\hline The Prime Minister Office & & & 2 & & & 2 \\
\hline TOTAL & & 6 & 189 & & & 195 \\
\hline
\end{tabular}

\section{CONCLUSION}

All Western Balkan countries are formal members of the OGP, but Kosovo. This indicates governments 'willingness to improve transparency, accountability, and value creation by making government data available to all. However, their willingness does not match with the current quality of data found in all government portals in the region.

The results show that the number of datasets in countries ranges from 76 in Montenegro to $305 \mathrm{in} \mathrm{BiH}$. However, the number of datasets published does not indicate higher quality of data. As shown in the analysis, $\mathrm{BiH}$ has the highest number of datasets available; however, it is one of the two lowest performers of data format quality, while Montenegro with the lowest number of datasets available is considered the best performer in the region, followed by Kosovo, according to the 5 star methodology.

Moreover, the analysis shows that only two countries, Montenegro and Kosovo, have established policies that instruct all organizations to publish in the same format. Another finding depicts that none of the countries has the highest quality of data rated with 5 stars. Moreover, Albania and North Macedonia being the two first countries to sign the OGP declaration do not show the best results in OGD quality. This depicts no correlation between the year the country signed the ODP and its state of play, thus indicating other factors that can potentially impact qualitative data such as political willingness or the government human and financial capacity.

Overall, the WB countries are still at an early stage of opening government data and providing high quality data for various purposes.

\section{REFERENCES}

Schrier, Bill. "Government open data: Benefits, strategies, and use." University of Washington Evans School Review 4 (2014): 12-27.

Bauer, F., \& Kaltenböck, M. (2011). Linked open data: The essentials. Edition mono/monochrom, Vienna

Buchholtz, S., Bukowski, M., \& Śniegocki, A. (2014). Big and open data in Europe: A growth engine or a missed opportunity. Warsaw Institute for Economic Studies Report Commissioned by demosEUROPA, 10 
Beck, K. and Ralph, J., 1994. Patterns Generates Architectures. Proceedings of European Conference of Object-Oriented Programming. Bologna, Italy, pp. 139-149.

Berners-Lee, T., Chen, Y., Chilton, L., Connolly, D., Dhanaraj, R., Hollenbach, J. \& Sheets, D. (2006, November). Tabulator: Exploring and analyzing linked data on the semantic web. In Proceedings of the 3rd international semantic web user interaction workshop (Vol. 2006, p. 159).

Zuiderwijk, A., \& Janssen, M. (2014). Open data policies, their implementation and impact: A framework for comparison. Government Information Quarterly, 31(1), 17-29.

Ubaldi, B., 2013. Open Government Data: Towards Empirical Analysis of Open Government Data Initiatives. OECD Publishing.

Janssen, M., Charalabidis, Y. \& Zuiderwijk, A., 2012. Benefits, Adoption Barriers and Myths of Open Data and Open Government. Information Systems Management, 29(4), pp. 258-268.

Tinholt, D. (2013). The Open Data Economy: Unlocking Economic Value by Opening Government and Public Data. Dulong de Rosnay, M., \& Janssen, K. (2014). Legal and institutional challenges for opening data across public sectors: Towards common policy solutions. Journal of theoretical and applied electronic commerce research, 9(3), 1-14.

Neelie, L. (2011) Vice-President of the European Commission responsible for the Digital Agenda. Opening Remarks, Press Conference on Open Data Strategy.

Gjergji.V (2018). Independent Reporting Mechanism: Albania End-of-Term-Report 2016-2018, OGP

Milena.L and Dragana.B (2018). Serbia Mid-of-Term-Report 2016-2018

Open Government Partnership. (2020). About - Open Government Partnership. [online] Available at: https://www.opengovpartnership.org/about/ [Accessed 25 Aug. 2019].

5stardata.info. (2019). 5-star Open Data. [online] Available at: https://5stardata.info/en/ [Accessed 20 Sep. 2019].

Opendata.me, (2019). [online] Available at: https://data.gov.me [Accessed 02 Oct. 2019].

Opendata.ba. (2019). [online] Available at: https://opendata.ba [Accessed 15 Oct. 2019].

OpenData - Faqja Kryesore. (2019). OpenData - Faqja Kryesore. [online] Available at: http://opendata.gov.al/ [Accessed 02 Nov. 2019].

whitehouse.gov. (2019). Transparency and Open Government. [online] Available at: https://obamawhitehouse.archives.gov/the-press-office/transparency-and-open-government [Accessed 25 Nov. 2019].

Opendata.rks-gov.net. (2019). Welcome - RKS Open Data. [online] Available at: https://opendata.rks-gov.net/en/ [Accessed 20 Oct. 2019].

Otvorenipodatoci.gov.mk. (2019). Добродојдовте - datagovmk. [online] Available at: http://www.otvorenipodatoci.gov.mk/ [Accessed 21 Nov. 2019].

Data.gov.rs. (2019). Почетак - Отворени подаци. [online] Available at: https://data.gov.rs/sr/ [Accessed 12 Oct. 2019]. 